\title{
Dimensions of Service Quality for Improvement of Employees Performance: Study in First Class Hotels in Alexandria Hassan Ali Mansour ${ }^{1}$ Wael Mahmoud Aziz ${ }^{2}$ EL Hussein Moawad Said ${ }^{3}$ \\ ${ }^{1}$ High Institute of Tourism and Hotel Management, Alexandria (EGOTH) \\ ${ }^{2}$ Faculty of Tourism and Hotels, Mansoura University. \\ ${ }^{3}$ Faculty of Tourism and Hotels, Fayoum University
}

\begin{abstract}
The purpose of this study is to identify dimensions quality for improvement employee's performance and their corresponding measurement variables in the tourism industry by focusing on four and five star hotels in Alexandria, due to customers focus on the level of services provided to him and increasing the competitiveness of hotel, for that this study focused to quality dimensions and it is buzzwords in hotels industry to improving the employee's performance, and included five main dimensions to achieve the goal of this research (Empathy, Reliability, Responsiveness, Assurance and Tangibles) their application in hotels not only represents a competitive target but that many organizations seeking to obtain certifications in quality to themselves and their employees that they have an integrated system of staff, a sound infrastructure and applied quality principles in all its divisions generally, In particular food and beverage department which is based on this study. To achieve this objective, the researcher surveyed 520 employees in upscale hotels in Alexandria. Data were analyzed using (SPSS 22).
\end{abstract}

Key words: Dimensions of Quality, Hotel Industry, Employee's Performance, Quality Management.

\section{Introduction}

Subject of quality and importance of their application in the hotels of the topics that received wide attention in the world of hospitality of different kinds and sizes (Crick \& Spencer, 2011). Quality issues in business have been responsible for the development your organizations and even industries, for instance, the American Society for Quality ,Six Sigma consulting and International Organization for Standardization (Kosar \& Raseta, 2005, Ladhari, 2009). Quality is given product to defined its ability to satisfy customer's needs, then the measure of a becomes a synonymous with quality assessment, customer's satisfaction Business success may simply be the extent to which you organization can produce a higher quality product or service than you competitors are able to do at a competitive price (Ivana et al, 2011). When quality is the key to a hotel success, quality allow organizations to keep up with and meet current quality levels, meet the consumer's requirement for quality, retain employees through competitive compensation programs, and keep up with the latest technology (walker , 2016). If the organization has succeeded in designing and total quality management program, this will be a strong base to build its quality systems, which in turn will equip the organization to comply with international standards for quality, environment and occupational health and safety, which will lead to increased customers both in the domestic market and international market to deal with those organizations that apply quality standards (Vivienne \& Nerilee, 2010) Given that these organizations have succeeded in designing and developing quality systems can trust them (Evans and Lindsay, 2008).

Karapetrovic \& Willborn (2009) affirmed that the perception of employees and their awareness of the importance of the application of quality systems are essential for the success of any service organization, where they contribute to solving problems faced by the various departments of the hotel, as it sheds light on the shortcomings and bugs 
and find solutions to them, they also contribute in guiding and hotel services provided for guests to achieve its goals in the fastest time and at the of service quality, which is important for creating financial benefit leading to a long-term competitive advantage for the hotel (Zhang et al, 2011).

According to (Grzinic, 2007) the quality of conformity with the design completes the first aspect because it represents the level to which the product/service meets the demands of the market. The quality represents the satisfaction of the client's needs and in order to achieve it and keep it in time, we not only need a continuous research into the demands of the clients but also of our own capabilities. Such an approach would ensure the pursuing of constant improvements according to the demands of the clients. (Sila, 2007) mentioned that the main aim of quality management is to identify those elements of a system which significantly influence the guest's perception quality of service and product that they receive.

\section{Literature Review}

Over the years the attention of practitioners and the academic literature on quality has significantly concentrated on measuring the quality in the manufacturing and service sector. However, the demand for better customer service has considerably increased the need for managing service quality (Wu et al, 2012). In the context of the hotel industry, quality in terms of both customer's expectation and customer's perception could lead to customer loyalty, enhanced image, reduced costs and increased business performance (Ramanathan, 2011). For this reason, one of the most important factors affecting hotel business performance is the improvement typically claim "I know it when I see it" (feel, taste, instinct and/or smell). These simple statement and the interpretations of quality made by lay people mask the need to define quality and its attributes in an operational manner. In fact, quality as a concept is quite difficult for many people to grasp and understand, and much confusion and myth surround it (Naseem et al, 2011).

According to Zhang (2016) the concept of the quality is topic which holds the central place in the services marketing. However, the attempt to define quality in scientific circles causes a number of dilemmas, the main reason for that lies in the fact that quality does not represent a purely "clear" scientific concept. Although the term "quality" is widely used in everyday speech, it is not often clear what that quality actually stands for, i.e. defining a quality can be a rather subjective concept.

According to Dale (2007) in the western world the best known quality management systems experts are all Americans (Crosby, 1979) stresses increasing provability through quality improvement. and reduces costs and raises profits, (Deming, 1982) He define quality in terms, and quality of the sales and service function, (Feigenbaum, 1983) an effective system for integrating the quality maintenance in company, and quality-improvement and enable marketing, engineering, production, (Juran, 1988) $\mathrm{He}$ the first to broaden the thinking in quality control by emphasizing the importance of. (Waller, 1996) added an interesting definition stating that quality is not necessarily the best or the most expensive product, (Gryna, 2001) how well a product does what it is intended to do. Basic parameters of quality were grouped into three areas: quality of design; quality of conformance; and quality of performance (Wildrick et al, 2002). Quality is multi-dimensional concept and different definitions are appropriate under different circumstances (Viswanadhan, 2006). 


\section{Service Quality in Hospitality Industry}

Zhang (2016) define service quality from the service provider's perspective as the degree to which the service's features comply with the organization's specifications and requirements; from the customer's perspective this implies whether the service meets or exceeds his or her expectations,. However, different provider-based and customer-based perspectives of service quality can be generated by subsequent encounters with the profit-oriented organization. Thus, this leads to an important concept in assessing quality from perceived service quality. Perceived service quality refers to the customer's evaluation of an organization's service based on his or her overall experience of the continuous service encounter (Ivana et al, 2011).

\section{Employee's Performance and Quality Management}

William (2008) observes that when employees begin a relationship with a business, he or she already has a specific set of expectations in the quality of the service to be provided. These expectations are based on their perceptions of the service provider, the hotel and the industry which are formed through past personal experience, the experience of others with whom the customer interacts, and the company's advertisements. Several studies in the hospitality industry such as studies carried out by (Mensah, 2009) and (Grzinic, 2007) look at service quality with respect to performance and/or customer satisfaction.

Measuring customer expectations is linked with measuring customer satisfaction and service quality (Natuhwera, 2011) suggests two approaches to the measuring of service quality; the "product based" approach and the "consumer oriented approach". The "product based" approach to the process of measuring the quality of service delivery such as the "Internal Service Quality" (INSQ), emphasized the need of product positioning, specification, communication, rating and staff training, motivation and reward systems. The second approach (Zhang, 2016) suggested is consumer oriented. Expectations are the basis for satisfaction. After consuming the service, consumers compare their earlier expectations with the present experience; results can range from satisfaction to dissatisfaction. The consumer anticipates the service standards in his expectations.

Alin (2010) proposed that employee's expectation is formed by many uncontrollable factors which include previous experience with other companies.

\section{Employees Performance in Hospitality Industry}

According to Michael (2006) Employees Performance is a systematic process for improving organizational performance by developing the performance of individuals and teams. The overall aim of Employees performance in hospitality industry is to establish a high performance culture in which individuals and team take responsibility for the continuous improvement of business processes and for their own skills and contributions within a framework provided by effective leadership (Barbara, 2009) So the objectives of both employees performance (Pareek \& Ra, 2006).

\section{Dimension of Service Quality}

institutions have different missions, and comparing them using product dimensions of service quality that are the goals of only a subset of the institutions in hotels industry leads to conclusions of doubtful value. Process dimensions give a fairer comparative picture of quality than do presage or product dimensions. However, different pedagogic phenomena, and hence different process variables, are likely to be salient 
in different institutions. Yarimoglu (2014) proposed the following dimensions of service quality, these are; see table (1).

Table 1: Dimension of Service Quality

\begin{tabular}{|c|c|c|}
\hline No & Dimension & Meaning and example \\
\hline 1 & Reliability & $\checkmark$ Service is carried out in the way it is promised. \\
\hline 2 & Responsiveness & $\checkmark$ Services are carried out promptly according to the \\
\hline 3 & Competence & customers. \\
\hline & & $\checkmark$ The staff of the service provider has the knowledge and \\
\hline 4 & Access & skills required for delivering the service. \\
\hline 5 & Courtesy & $\checkmark$ Concerns, e.g. opening hours, physical location, etc. \\
\hline 6 & Communication & $\checkmark$ The staffs are polite, friendly, respectful, etc. \\
\hline 7 & Credibility & $\begin{array}{l}\text { Keeping the customers in formed in a language that they } \\
\text { can understand and listening to them. }\end{array}$ \\
\hline 8 & Security & $\checkmark$ Service provider is trustworthy, believable and honest. \\
\hline 9 & Understanding & $\checkmark \quad$ Free off danger, risk or doubt. \\
\hline & the customer & $\checkmark$ Service provider makes an effort to understand the needs \\
\hline 10 & Tangibles & and requests of the individual customers. \\
\hline & & $\begin{array}{l}\text { physical objects that are needed for carrying out the } \\
\text { service such as facilities, equipment, etc. }\end{array}$ \\
\hline
\end{tabular}

Source: Yarimoglu (2014)

According to (Bezerra \& Gomes, 2015) Market dimension of quality is seen as an outcome, or cue, of to employee's performance rather than an element of product quality. A high price may inform about high quality, and a higher price may be accepted when high quality is valued when applied quality systems. Accordingly, the connection between objective (measurable) quality and dimension of service quality has been noted to be normally positive, even though often at best modest.

To measure perceived service, (Biljana, 2011) identifies ten key determinants of service quality, which impact both expected and perceived services, and through those, perceived service quality (Figure 1) Expected service is also influenced by word of mouth, personal needs as well as past experience.

Figure 1: Determinants of Service Quality.

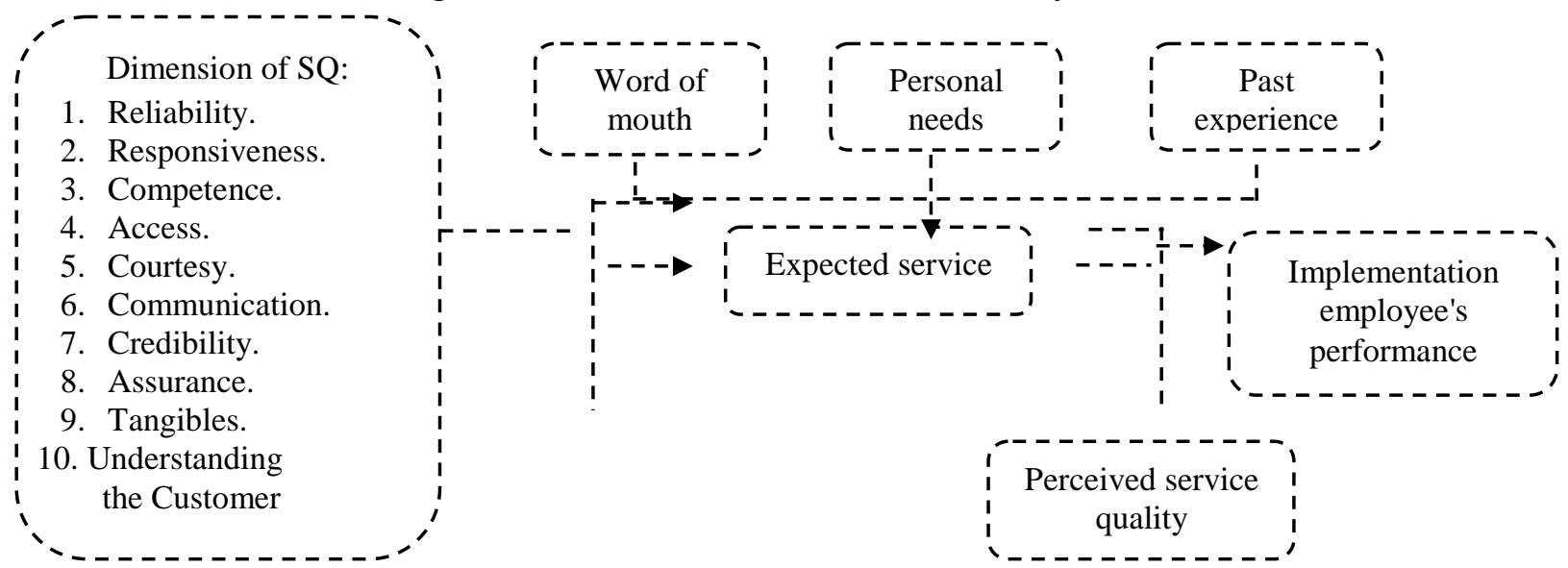

Source: (Biljana, 2011).

\section{Measurement of Service Quality:}

According to Sheetal and Harsh (2004) There are two perspectives of quality measurement: internal and external. According to internal perspective, it is defined as zero effect doing it right the first time, or conformance to requirements. The external 
perspective understands this aspect it in terms of customer perception, customer expectation, customers satisfaction, and customer delight.Comparing customer's expectations and their perceptions of actual performance can be done by making use of the service quality scale (SERVQUAL) created by (Biljana, 2011) which specifically designed for use in the service sector. This relationship survey comprises of twenty two multidimensional questions about all facets of the relationship of the customer with the service, (Zeithaml and Bitner, 2009).

Melisidou and Theocharis, (2010) refer that SERVQUAL tool has received some criticism, but has been used to measure service quality in a variety of industries with much success. One criticism about the SERVQUAL dimensions was related to more fundamental methodological and conceptual issues, for example, the presence of conceptual inconsistency in the dimensions.

Measurement of service quality in the service sector should take into account customer expectations of service as well as perceptions of service, "It is apparent that there is little consensus of opinion and much disagreement about how to measure service quality" The SERVQUAL instrument has been the predominant method used to measure consumers' perceptions of service quality. It has five generic dimensions or factors and is stated as follows (Yarimoglu, 2014):

(1)Tangibles: Physical facilities, equipment and appearance of personnel.

(2) Reliability: Ability to perform the promised service dependably and accurately.

(3) Responsiveness: Willingness help customers provide prompt service.

(4) Assurance (including competence, courtesy, credibility and security), Knowledge and courtesy of employees and their ability to inspire trust and confidence.

(5)Empathy (including access, communication, understanding the customer), individualized attention that the firm provides to its customers.

\section{Important of Employees Performance}

Generally EP was incorporated for a number of potential agendas (Swart et al., 2005) noted that some of the agendas that lead to E.P procedures being conducted within an organization include:-

1. Improvement in the communication between boss and subordinate through the use of feedback between them.

2. Identification of the scope for performance improvement and the

Mean to achieve this.

3. Identification of individual training and development needs.

4. Identification of the potential of individuals for future promotion, succession planning, or for retention or termination purposes.

5. As the basis for remuneration and reward, on the basis of performance.

6. As a powerful means of managerial control, through the setting of objectives in a hierarchical fashion and a review of success or failure in achieving these.

The purpose of job evaluation techniques is to measure the relative worth of jobs cab be expressed in salary and wage scales, based on a logical, ordered system ."Job evaluation "is a term used in a general way for a number of techniques that are in different forms. These techniques entail analyzing and assessing the content of jobs so that they may be classified in an order relating to one another and to the market place (Shaun and Alfred, 2012). 


\section{Research Methodology}

This chapter gives the aims of the primary research, outlines the principle research techniques available, the justification for the choice of techniques used, and details, and finally shows the specific questionnaire form answer the study hypotheses.

This study aim to assess and identify the dimensions of quality for improvement employee's performance, to objective of the study it was necessary to determine the extent to which the hotel adopted the concepts of quality and highlight the role of quality management as a key element in the administrative mix in order to achieve the objectives of the hotel, The study was identified by the hotel's food and beverage department, Because it is considered one of the most important sections within the hotel, Originally the questionnaire was designed in English. The decision was made to translate the research questionnaire into Arabic and to distribute the questionnaire because of the official language in Egypt, to make it very clear for the respondents.

\section{Population and Sample}

The target population for this study is employees in Food and Beverage department in four and five star hotels in Alexandria, which consists of fifteen hotels and the total number of employees representing about (1300) employees according to (Human Resource Department in Hotels) while a sample of this study consists of (520) employees; which was selected randomly. Questionnaire design was divided into two main sections, the first one is consists of question about demographic factors of employees in food and beverage department in four and five star hotels in Alexandria. The total number of hotels is 18 hotels according to (Egyptian Hotels Associations, 2017) but this study is adopted 15 hotels four and five star hotels in Alexandria, The second construct: is determining the employee's performance according to service quality dimensions, is consists of (20) question, the uses scale is (Likert Scale) is a five point. Reliability Analysis is 0.7841 was used to measure reliability using Cronbach alpha.

\section{Study Hypotheses}

H1: There is significant relationship between demographic factors of employees and dimensions of service quality.

$\mathrm{H} 2$ : There is significant relationship between dimensions of service quality and employees performance.

\section{Results and Discussions:}

Demographic Factors:

Table 2: Employees of Responds in Surveyed Hotels

\begin{tabular}{|l|c|c|l|c|c|}
\hline Attribute & \multicolumn{2}{|c|}{$\mathrm{N}=520$} & Attribute & \multicolumn{2}{c|}{$\mathrm{N}=520$} \\
\hline & $\mathrm{N}$ & $\%$ & & $\mathrm{~N}$ & $\%$ \\
\hline Gender : & & & Educational & & \\
Male & 375 & 72 & Qualification about & & \\
Female & 145 & 28 & work : & 333 & 64 \\
\hline Age : & & & Yes & 187 & 36 \\
$18<30$ & 333 & 64 & No & & \\
\cline { 4 - 6 } $31<40$ & 135 & 26 & Experience : & & \\
$41<50$ & 42 & 8 & Less than 2 year & 156 & 30 \\
More than 50 & 10 & 2 & $2<5$ & 317 & 61 \\
& & & $5<10$ & 26 & 5 \\
& & & More Than 10 & 21 & 4 \\
\hline
\end{tabular}




\begin{tabular}{|l|c|c|l|c|c|}
\hline Position: & & & Classification : & & \\
Management & 31 & 6 & 4 Stars & 165 & 32 \\
Supervisor & 52 & 10 & 5 Stars & 355 & 68 \\
Employee & 437 & 84 & & & \\
\hline Education : & & & Ownership : & & \\
High School & 31 & 6 & International Chain & 374 & 72 \\
Diploma & 94 & 18 & Local Chain & 104 & 20 \\
University & 354 & 68 & Private Sector & 42 & 8 \\
Postgraduate & 41 & 8 & & & \\
\hline
\end{tabular}

The previous table (2) shows that the population study of employees in the four and five star hotels in Alexandria represents 520 employees in the food and beverage department of the population study hotels .The table above shows the demographic factors of the workers and tests the Hypotheses four (H2) "There is Statistically Significant Relationship Between Demographic Factors of Employees and dimensions of service quality, it is as follows:

Gender of Employees: The table shows that male workers accounted for $72 \%$ of the total number of 375 of Males; Compared with the number of females is 145 with percentage 28\%, in population study hotels in Food and Beverage Department. The reason for this the most hotels rely on workers from Males are more likely than females because the conditions and nature of work in the food and beverage department to work hard and serious,

\section{Testing Hypotheses}

Table 3: Correlation of Gender with Dimensions of Service Quality

\begin{tabular}{|c|c|c|}
\hline \multicolumn{2}{|c|}{ Constructs } & $\begin{array}{c}\text { Dimensions of } \\
\text { Service Quality }\end{array}$ \\
\hline \multirow{4}{*}{ Gender } & Persons Correlation & $.529^{*}$ \\
\cline { 2 - 3 } & Sig. (2-tailed) & .002 \\
\cline { 2 - 3 } & $\mathrm{N}$ & 520 \\
\hline
\end{tabular}

Using correlations to test the study hypotheses about gender, Table (3) revealed that there is positive and medium relationship between gender and dimensions of service quality $(\mathrm{R}=0.529)$.

\section{Age of Employees}

The majority of the study population is (18-30) years with percentage 64\% employees in the food and beverage department. And second choice is (31-40) years with percentage $26 \%$, finally, show results (41-50) and (more than 50) years are a less age group and their all percentage is $10 \%$. Commenting on the results shows that, the food and beverage department in hotels is depends on the youth to accomplish their work, and the researcher explains that this is because the first category the age group has the ability to bear the burdens and conditions of hard work and secondly many of hotels they look at to this category as a cheap labor, this is confirmed by (Quilliam, et al. ,2014) he said the truth is that there are some jobs on board for which applicants over the age of 35 would not be considered. The main concern for the employer is that the job-seeker is fit, both physically and medically. The other concern is would the applicant fit into a team of mostly younger crew members.

Table 4: Correlate Age with Dimensions of Service Quality 
International Journal of Heritage, Tourism and Hospitality Vol. (12), No. (2/2), September, 2018 By: Faculty of Tourism and Hotels, Fayoum University, Egypt

\begin{tabular}{|c|c|c|}
\hline \multicolumn{2}{|c|}{ Constructs } & $\begin{array}{c}\text { Dimensions of } \\
\text { Service Quality }\end{array}$ \\
\hline \multirow{3}{*}{ Age Group } & $\begin{array}{c}\text { Persons } \\
\text { Correlation }\end{array}$ & $.711^{* *}$ \\
\cline { 2 - 3 } & Sig. (2-tailed) & .000 \\
\cline { 2 - 3 } & $\mathrm{N}$ & 520 \\
\hline
\end{tabular}

According correlations to test the study hypotheses about age group, Table (4) revealed that there is positive and strong relationship between age and Application Dimensions of Service Quality $(\mathrm{R}=0.711, \mathrm{P}<.000$ and $\mathrm{H} 1$ supported.

- Function: The data in previous table (4) indicate when the workers were asked about their job. The results of the study population showed that the majority of the members are employees with percentage $84 \%$, and supervisors is percentage $10 \%$, while came in last place are the management, where it came at $6 \%$.

Table 5: Correlate Function with Dimensions of Service Quality

\begin{tabular}{|c|c|c|}
\hline \multicolumn{2}{|c|}{ Constructs } & $\begin{array}{c}\text { Dimensions of } \\
\text { Service Quality }\end{array}$ \\
\hline \multirow{3}{*}{ Function } & $\begin{array}{c}\text { Persons } \\
\text { Correlation }\end{array}$ & $-.225^{*}$ \\
\cline { 2 - 3 } & Sig. (2-tailed) & .024 \\
\cline { 2 - 3 } & $\mathrm{N}$ & 520 \\
\hline
\end{tabular}

Correlations test the study hypotheses about position, the pervious Table (5) showed that there is Reverse relationship between Function and Dimensions of Service Quality $\left(\mathrm{R}=-.225^{*}\right)$.

Level of Education : where it was found that the majority of the study population have a university education with percentage $68 \%$, and the second choice is education diploma with percentage $18 \%$, finally was found high school and postgraduate Less selection was percentage $12 \%$,from the point of view of the researcher is the reason that the national trend of many people, In Alexandria, many parents are forced to teach their children a university education so that they have the opportunity to find a suitable job for them in the future (regardless of living conditions and the state of the country now), While the majority of hotels aren't requiring managers to become certified, some larger hotel chains are starting to, especially for general manager positions.

Table 6: Correlattion Level of Education with Dimensions of Service Quality

\begin{tabular}{|c|c|c|}
\hline \multicolumn{2}{|c|}{ Constructs } & $\begin{array}{c}\text { Dimensions of } \\
\text { Service Quality }\end{array}$ \\
\hline \multirow{3}{*}{$\begin{array}{c}\text { Level of } \\
\text { Education }\end{array}$} & $\begin{array}{c}\text { Persons } \\
\text { Correlation }\end{array}$ & $-.535^{* *}$ \\
\cline { 2 - 3 } & Sig. (2-tailed) & .601 \\
\cline { 2 - 3 } & $\mathrm{N}$ & 520 \\
\hline
\end{tabular}

Using correlations to test the study hypotheses about level of education, Table (6) revealed that there is reverse relationship between education and with dimensions of service quality $(\mathrm{R}=0.529)$, according to results the standard of work efficiency is not the educational level, but experience and ability to perform tasks required and efficiency Is the true criterion to evaluation employees.

Experience: The results presented in the question indicate the years of experience. The majority of the results of the study sample indicate that the years of experience 
ranging from $2: 5$ is the largest choice, representing $61 \%$. And the second choice is (less than 2 years) with percentage $30 \%$, and finally choice (5:10 and more than 10 years) with percentage $9 \%$. Commenting on the data received, the majority of employees in the food and beverage department are young, as we mentioned earlier. It is known that the hotel sector has a high turnover rate due to the fact that many, this results agree with (Chapmann and Loveall, 2006) he said you'll receive training along with your hands-on experience, but most management-training programs are reserved for those with college degrees who show leadership potential.

Table 7: Correlation of Experience with Dimensions of Service Quality

\begin{tabular}{|c|c|c|}
\hline \multicolumn{2}{|c|}{ Constructs } & $\begin{array}{c}\text { Dimensions of } \\
\text { Service Quality }\end{array}$ \\
\hline \multirow{3}{*}{ Experience } & Persons Correlation & $.506^{* *}$ \\
\cline { 2 - 3 } & Sig. (2-tailed) & .004 \\
\cline { 2 - 3 } & $\mathrm{N}$ & 520 \\
\hline
\end{tabular}

According correlations to test the study hypotheses about experience, Table (7) revealed that there is positive and strong relationship between experience and Dimensions of Service Quality $\left(\mathrm{R}=.506^{* *}\right)$ and $\mathrm{H} 1$ supported.

Classification of Hotels: Through the data received when employees asked about classification of hotels in which they work, in population study shows that the total number of worked is 281 with percentage $54 \%$ and the total number of worked in four stars hotels come percentage $(46 \%)$ of the study population.

Table 8: Correlation of Classification of Hotels with Dimensions of Service Quality

\begin{tabular}{|c|c|c|}
\hline \multicolumn{2}{|c|}{ Constructs } & $\begin{array}{c}\text { Dimensions of } \\
\text { Service Quality }\end{array}$ \\
\hline \multirow{3}{*}{$\begin{array}{c}\text { Classification } \\
\text { of Hotels }\end{array}$} & Persons Correlation & $.866^{* *}$ \\
\cline { 2 - 3 } & Sig. (2-tailed) & .000 \\
\cline { 2 - 3 } & $\mathrm{N}$ & 520 \\
\hline
\end{tabular}

Using correlations to test the study hypotheses about classification of hotels, Table (20) revealed that there is strong relationship between classification of hotels and dimensions of service quality $\left(\mathrm{R}=.866^{* *}\right)$.

Ownership of Hotels: the ownership of the hotels population study. The results of the questionnaire indicate that the total number of international chain hotels is percentage $72 \%$, and second choice is local chain hotels it come was percentage $20 \%$, and finally choice is private sectors was percentage $8 \%$.

Table 9: Correlation of Ownership of Hotels with Dimensions of Service Quality

\begin{tabular}{|c|c|c|}
\hline \multicolumn{2}{|c|}{ Constructs } & $\begin{array}{c}\text { Dimensions of } \\
\text { Service Quality }\end{array}$ \\
\hline \multirow{4}{*}{$\begin{array}{c}\text { Ownership of } \\
\text { Hotels }\end{array}$} & Persons Correlation & $.912^{* *}$ \\
\cline { 2 - 3 } & Sig. (2-tailed) & .002 \\
\cline { 2 - 3 } & $\mathrm{N}$ & 520 \\
\hline
\end{tabular}

According to the data in the previous table (9), using correlations to test the study hypotheses about ownership of Hotels, revealed that there show that the strong relationship between ownership of hotels and dimensions of service quality $\left(\mathrm{R}=.912^{* *}\right)$.

\section{Hotel Adopt Standard of Quality Management}


International Journal of Heritage, Tourism and Hospitality Vol. (12), No. (2/2), September, 2018 By: Faculty of Tourism and Hotels, Fayoum University, Egypt

From the data in the previous question, which explains the opinions of the hotel staff, the following can be explained in the following table:-

Table 10: Adopt Standard of Quality Management

\begin{tabular}{|c|c|c|c|c|c|}
\hline & & Frequency & Valid Percent & Mean & $\begin{array}{c}\text { Std. } \\
\text { Deviation }\end{array}$ \\
\hline \multirow{2}{*}{ Valid } & Yes & 372 & 72.0 & & \\
\cline { 2 - 6 } & No & 148 & 28.0 & 1.28 & 0.45 \\
\hline \multicolumn{2}{|c|}{ Total } & 520 & 100.0 & & \\
\hline
\end{tabular}

The previous table (10) shows that the majority of the study population is oriented towards selection (Yes) was percentage $72 \%$, and selection (No) was percentage $28 \%$, and the mean is 1.28 , and standard deviation is 0.45 , and comments of the data Interpretation of the results shows that the majority of the study population which operate in hotels that are implementation the concepts quality management. 
International Journal of Heritage, Tourism and Hospitality Vol. (12), No. (2/2), September, 2018

By: Faculty of Tourism and Hotels, Fayoum University, Egypt

\section{Dimension of Service Quality}

Table 11: Frequency, Mean and standard devotion of Dimension of Quality

\begin{tabular}{|c|c|c|c|c|c|c|c|c|c|c|c|c|c|c|c|c|}
\hline \multirow{2}{*}{ NO } & & \multicolumn{2}{|c|}{ S Agree } & \multicolumn{2}{|c|}{ Agree } & \multicolumn{2}{|c|}{ Neutral } & \multicolumn{2}{|c|}{ Not Agree } & \multicolumn{2}{|c|}{$\begin{array}{l}\text { S Not } \\
\text { Agree }\end{array}$} & \multirow{2}{*}{ 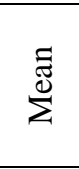 } & \multirow[b]{2}{*}{ Std.D } & \multirow[b]{2}{*}{ C.V } & \multirow{2}{*}{$\underset{\mathrm{Z}}{\mathrm{A}}$} & \multirow[b]{2}{*}{$\operatorname{Sig}^{* *}$} \\
\hline & & Freq & $\%$ & $\begin{array}{c}\text { Fre } \\
\mathrm{q}\end{array}$ & $\%$ & Freq & $\%$ & Freq & $\%$ & Freq & $\%$ & & & & & \\
\hline \multirow[t]{5}{*}{1} & Tangibles & & & & & & & & & & & & & & & \\
\hline & $\begin{array}{l}\text { Satisfied with the level of service provided } \\
\text { to customers. }\end{array}$ & 276 & 54 & 214 & 40 & 22 & 4 & 8 & 2 & - & - & 1.54 & .67 & 43.50 & 2 & .000 \\
\hline & $\begin{array}{l}\text { Tools and materials are available to } \\
\text { perform work as required. }\end{array}$ & 220 & 43 & 175 & 33 & 52 & 10 & 73 & 14 & - & - & 1.96 & .91 & 53.06 & 6 & .000 \\
\hline & $\begin{array}{l}\text { The tools used to perform the work are } \\
\text { good condition. }\end{array}$ & 176 & 34 & 157 & 30 & 93 & 18 & 68 & 13 & 26 & 5 & 2.25 & 1.02 & 53.33 & 8 & .000 \\
\hline & $\begin{array}{l}\text { Satisfied with the service quality provided } \\
\text { to customers in terms of (taste, smell, color } \\
\text { and required). }\end{array}$ & 182 & 35 & 264 & 50 & 42 & 8 & 18 & 4 & 14 & 3 & 1.90 & .84 & 49.47 & 5 & .000 \\
\hline \multirow[t]{5}{*}{2} & Reliability & & & & & & & & & & & & & & & \\
\hline & $\begin{array}{l}\text { The working hours specified to me is very } \\
\text { appropriate to work. }\end{array}$ & 155 & 30 & 163 & 32 & 73 & 13 & 88 & 17 & 42 & 8 & 2.41 & 1.29 & 53.52 & 12 & .000 \\
\hline & $\begin{array}{l}\text { There is a benefit from customer } \\
\text { complaints about the Employees } \\
\text { performance and improve them. }\end{array}$ & 121 & 23 & 132 & 24 & 54 & 10 & 115 & 22 & 98 & 19 & 3.25 & 1.38 & 42.46 & 15 & .000 \\
\hline & $\begin{array}{l}\text { I aware service offered to customers must } \\
\text { be of high quality and highest level. }\end{array}$ & 220 & 43 & 175 & 33 & 52 & 10 & 73 & 14 & - & - & 1.47 & .65 & 44.21 & 1 & .000 \\
\hline & $\begin{array}{l}\text { The time taken to prepare food is timely } \\
\text { (20 minutes). }\end{array}$ & 205 & 39 & 220 & 43 & 77 & 15 & 18 & 3 & - & - & 1.81 & .80 & 44.19 & 3 & .000 \\
\hline \multirow[t]{5}{*}{3} & Responsiveness & & & & & & & & & & & & & & & \\
\hline & $\begin{array}{c}\text { There is collaboration between F\&B } \\
\text { departments to provide service perfectly. }\end{array}$ & 84 & 16 & 104 & 20 & 69 & 13 & 129 & 25 & 134 & 26 & 3.25 & 1.44 & 44.30 & 18 & .000 \\
\hline & $\begin{array}{l}\text { I am satisfied with the work and I do it } \\
\text { perfectly. }\end{array}$ & 84 & 16 & 94 & 18 & 74 & 14 & 154 & 30 & 114 & 22 & 3.24 & 1.40 & 43.20 & 16 & .000 \\
\hline & $\begin{array}{l}\text { There is a quick response to customer } \\
\text { requests and response to complaints. }\end{array}$ & 99 & 19 & 94 & 18 & 49 & 9 & 149 & 29 & 129 & 25 & 3.27 & 1.47 & 44.95 & 19 & .000 \\
\hline & $\begin{array}{l}\text { The employees are complete the work and } \\
\text { timely manner. }\end{array}$ & 114 & 22 & 172 & 33 & 42 & 8 & 104 & 20 & 88 & 17 & 2.62 & 1.41 & 46.38 & 17 & .000 \\
\hline 4 & Assurance & & & & & & & & & & & & & & & \\
\hline
\end{tabular}


International Journal of Heritage, Tourism and Hospitality Vol. (12), No. (2/2), September, 2018

By: Faculty of Tourism and Hotels, Fayoum University, Egypt

\begin{tabular}{|c|c|c|c|c|c|c|c|c|c|c|c|c|c|c|c|c|}
\hline & $\begin{array}{l}\text { I always Security and stability about work } \\
\text { in hotel. }\end{array}$ & 69 & 13 & 84 & 16 & 79 & 15 & 149 & 29 & 139 & 27 & 3.41 & 1.37 & 40.17 & 14 & .000 \\
\hline & $\begin{array}{l}\text { I work with my colleagues spiritually like } \\
\text { one team. }\end{array}$ & 164 & 32 & 144 & 28 & 49 & 9 & 109 & 21 & 54 & 10 & 2.49 & 1.18 & 55.42 & 11 & .000 \\
\hline & $\begin{array}{l}\text { I feel comfortable when I go to the } \\
\text { supervisor to tell him any problem. }\end{array}$ & 174 & 34 & 154 & 30 & 24 & 4 & 104 & 20 & 61 & 12 & 2.46 & 1.09 & 55.13 & 10 & .000 \\
\hline & $\begin{array}{l}\text { I satisfied with the service provided to me } \\
\text { by HR. }\end{array}$ & 144 & 28 & 44 & 8 & 64 & 12 & 119 & 23 & 149 & 29 & 3.17 & 1.50 & 52.89 & 20 & .000 \\
\hline 5 & Empathy & & & & & & & & & & & & & & & \\
\hline & $\begin{array}{l}\text { Comments provided to guests are } \\
\text { sufficient about work. }\end{array}$ & 159 & 30 & 119 & 24 & 54 & 10 & 79 & 15 & 109 & 21 & 2.21 & 1.08 & 42.41 & 9 & .000 \\
\hline & $\begin{array}{l}\text { I respect the customer's needs to get to } \\
\text { their satisfaction. }\end{array}$ & 213 & 41 & 227 & 43 & 57 & 11 & 23 & 5 & - & - & 1.81 & .80 & 44.19 & 3 & .000 \\
\hline & $\begin{array}{l}\text { The High desire of hotel Access is } \\
\text { customer's needs. }\end{array}$ & 162 & 31 & 160 & 30 & 30 & 6 & 107 & 21 & 61 & 12 & 2.16 & .98 & 55.13 & 7 & .000 \\
\hline & $\begin{array}{l}\text { I receive training on a regular basis to meet } \\
\text { the customer's needs. }\end{array}$ & 160 & 31 & 90 & 18 & 73 & 14 & 153 & 29 & 44 & 8 & 2.41 & 1.29 & 53.52 & 12 & .000 \\
\hline \multicolumn{12}{|c|}{ 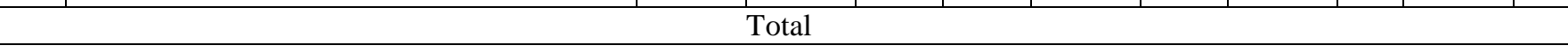 } & 49.09 & 22.57 & 959.3 & & .000 \\
\hline \multicolumn{12}{|c|}{ Total Mean } & 2.45 & 1.12 & & & \\
\hline
\end{tabular}


from the results in the previous table (11) regarding the employees' responses about dimension of quality requirements of improvement the employees performance, that the total mean is (2.53) and the standard deviation is (1.14), less than half the mean, Therefore The data are distributed in a normal distribution and the dispersion rate is acceptable, There is a strong moral significance this also indicates results toward is acceptable hypotheses (H2) as "there is statistically significant relationship between dimension of quality requirements to develop the employees performance in hotels". According to the data in the previous table (11) the first axis (Tangibles ) indicated that in first question : the opinion of employees in the study population heading to (Agree and Strongly Agree) about question satisfied with level of service provided to customers, with percentage $94 \%$, and the arithmetic mean was 1.54 and the standard deviation is 0.67 , which is confirmed by (Mostafa, 2007) customer focused and get satisfy about the customers need in hotels is a clear set of customer service performance standards that is systematically reinforced employees'. the second question about tools and basic materials are available to perform the work as required the percentage is $76 \%$, and the arithmetic mean was 1.96 and the standard deviation is 1.04, therefore If the tools and equipment available in hotels this helps employees to get works perfectly, this is consistent with (Quilliam et all, 2014) tools and equipment and basic materials are integral to a hotel's growth and success. Question three about the tools and equipment used to perform the work are in good condition. The employees' response was (Agree and Strongly Agree) with percentage 64\% approval, with mean of 2.25 and the standard deviation is 1.20 this confirmed by (Naseem et all, 2010) where they stressed that the staff needs to take the help of various cleaning equipment while trying to keep the hotel premises to the highest standard of appearance to get a good performance and make customers' needs. Fourth question satisfied about level of food provided to customers in terms of (Taste, Smell, Color and Required Settlement) with percentage 85\% approval, with mean of 1.90 and the standard deviation is 0.94 , so that the strong morale level. This result is consistent with (Natuhwera, 2011) because (color, taste smell, and required settlement) is everywhere it affects people at some level of consciousness, many early cultures consumed foods exclusively based level of food and beverage provided because emotional and physical properties associated with a good quality, they believed would be passed to the individual after consumption.

The second axis (Reliability) indicated that in first question about working hours specified to me is very appropriate to the amount of work, with percentage $62 \%$. The mean was 2.41 and the standard deviation is 1.29 was less than half of the mean, the results comment shows that the majority of the population study is acceptable about working times specified to the amount work, this data is agree with (Nicula and Posa, 2014) The primary technique towards achieving this goal of work, mandating of limits on the hours that can be worked in each day is availability work time to get all of time work perfectly to do his jobs. The second question about the customer complaints is benefit from work about the employee's performance and make to improve them is (Agree and Strongly Agree) with percentage $48 \%$, and the mean is 3.25 and standard deviation is 1.38 , that the strong morale level, that the most of results employees is accept about the customers complain to employees performance to improve the work, this result is agree with (Constantinescu, 2011) complaints should be considered an indicator of organizational performance assessment, signaling problems or failures in internal processes that need quick recovery in order to avoid migration of profitable customers, hotels establishments must learn that the consequences of losing customers are both profit decrease. According to the third 
question about the service is offered to customers must be of high quality and at the highest level is (Agree and Strongly Agree) with percentage $76 \%$, and the mean is 1.47 and standard deviation is 0.65 , that the strong morale level, that the most of results employees is accept about that the service is provided to guest must be good quality and high performance, this is confirmed by (Kim and Jogaratnam ,2010) because most of the processes in the hospitality sectors are relatively related with the service for external customers, quality in the process, timing, interruption in cooperation will affect all the goods and service being offered to external customers, Internal customer satisfaction has been recognized as a component of organizational commitment. Fourth question about the time taken to prepare food is timely with percentage $82 \%$, and the mean is 1.81 and standard deviation is 0.80 , less than half the center, the data distributed natural and dispersion rate is acceptable and there was a strong moral significance, the comment of the results refers the majority of the population study is accept about preparing food in timely to customers' needs and they are keen on timely manner.

The third axis (Responsiveness) indicated that in first question about collaboration between $\mathrm{F} \& \mathrm{~B}$ departments to satisfy the customers the results was percentage $51 \%$ disagree about this, with the mean is 3.25 , and standard division is 1.44 , This is an indication the results is oriented toward disagree, that the difference between the positive differences is significant where the value of the difference coefficient was 44.30, this results is reverse about was said (Wu et all ,2010) he is confirmed to F\&B department is a part of a hotel that manages foods and beverages, while in specific, F\&B Department is a part of a hotel department that manage and responsible to the service of F\&B necessary, and must be cooperation between the hotel sections to get the service quality. the second question about satisfied with the work and do it perfectly, the mean is 3.24 , and the standard deviation is 1.40 the difference between the positive differences is significant where the value of the difference coefficient was 43.20 at a significant level of $<0.001$, this is confirmed by (Crick and Spencer ,2011) that five basic steps in handling performance problems, Identify and agree through analyzing feedback and getting agreement from the employee what the shortfall has been, establish the reasons for the shortfall and avoid crudely attaching blame for problems in the job, decide and agree on the action required. Third question quick response to customer requests and response their complaints, with percentage is 54\% and the arithmetic mean was 3.27 and the standard deviation is 1.47. (Gajanan, 2014) refers to the staff should have a pleasant manner, showing courtesy and tact, an even temper and good humor, and never displeasure even though at times things may be difficult. They should never argue with a customer and if they cannot deal with the situation. Remember loss of time in dealing with complaints only makes the situation worse. Fourth question about question employees are complete the work entrusted to them and in a timely manner, with percentage is $51 \%$, and the arithmetic mean was 2.62 and the standard deviation is 1.41. Shi and $\mathrm{Su}$ (2007) confirmed to the hotel employees generally perceive that only two things are important in service quality, one is get the customer's needs and other is courtesy of employees but other aspects that make a standard of hospitality and important for service quality improvement are get this service in timely manner in hotel along with previous two aspects.

The fourth axis about (Assurance) indicated that in first question about question always security and stability about work in hotel, with percentage $61 \%$, and the arithmetic mean was 3.41 and the standard deviation is 1.37 , which is confirmed by (Kipsegerwo et al., 2016) this is one of the most important factors which are needed to be taken care of well by the employers. Besides, providing safe cab 
facility they have to ensure that employees many of reasons make the note secure about work we mention them, do not work late hours. Second question work with my colleagues like one Team, they were percentage $60 \%$ with arithmetic mean average of 2.49 and a standard deviation is 1.38 , This was confirmed by (Derven, 2010) It helps to develop your working practices to understand the points of view of your colleagues and to understand why they do things a certain way. And it spreads good practice throughout an organization. Third question about the question feels comfortable when go to the supervisor and tell him about any problem, where the approval percentage $64 \%$, where the mean was 2.46 and the standard deviation is 1.43 , less than half of the mean, this concurrent with (Huseyin and Rukiya, 2015) he added the modern systems for performance appraisal depersonalize issues. Supervisors focus on behaviors and results, rather than on personalities. Such systems support ongoing communication, feedback and dialogue about organizational goals. Also they support communication between an employee and a supervisor. The last question about axis assurance is of question satisfied with the service provided by HR and training department, where the mean was 3.17 and the standard deviation was 1.60 , as was observed when analyzing the same data difference between the sub-items is significant differences and this the results reversing what he stressed by (Djabatey, 2012) human resource function refers to the individuals within an organization whose activities contribute to the organization s success and that is that the control of performance is an important part of the work performance and that effective evaluation leads to increase the sense of belonging and loyalty to the hotel and significantly affect the level the individual performance.

The last axis about (Empthy) indicated that in first question about comments provided by guests are sufficient about work, was percentage 54\% acceptable about this, with the mean is 2.21, and standard division is 1.08, this results is agree with (Al-otaibi, 2015) one of the most popular is a guest comment card (GCC), which has the advantages of small size, easy distribution, and simplicity. Second question about the question Respect the customer's needs to get to their satisfaction, with percentage $84 \%$, and the mean is 1.80 , and the standard deviation is 0.80 , and the value of the difference coefficient was 44.19 , the comment in the results show that the most of population study is acceptable about customers need respect to get the customers satisfaction, this consist with (Alin, 2010) satisfaction is a person's feelings of pleasure or disappointment resulting from comparing a product's perceived performance (or outcome) in relation to his or her expectation, customer's evaluation to the consumption experience with the services. Questions three the percentage $61 \%$ agreement and the mean of 2.16 and the standard deviation is 0.98 , and the value of the difference coefficient was 55.13 this concurrent with (Natuhwera, 2011) confirms that Expectations are the basis for satisfaction. After consuming the service, consumers compare their earlier expectations with the present experience. Finally questions about receive training to meet the customer's Needs, with percentage 49\%, arithmetic mean average of 2.14 and a standard deviation of 1.29. There is a strong moral significance. the value of the different coefficient was 53.52 the results are consisted with (Nischithaa and Narasimha, 2014) where they stressed the importance of employees, training programs for the employees are working to improve the performance and develop according to the objectives of the hotel, which makes employees feel satisfaction and enhance their moral spirit. 


\section{Conclusion}

This study examined the aspects of dimensions of service quality for improvement employee's performance in hotels that influence the satisfaction of customers. The findings of this study suggested that impact of service quality effects of improvement employee's performance that results in success of hotel and it is an irrefutable fact. Furthermore, sustaining the customer satisfaction level is an ongoing process that requires continuous improvement in service quality at hotels.

Based on study findings, it can be concluded that employees performance' perceptions regarding hotel brand service quality dimensions such as "Tangibles, Reliability and Empathy" contributed to build their satisfaction rather than "Responsiveness and Assurance". It is therefore essential for managers in hotel industry to apply the SERVQUAL model for the measurement of service quality to improvement employee's performance, in order to satisfy the guest's expectations.

Dimensions of service quality are a systematic quality approach, use of which leads and improving employee's performance. Maximizing the role of quality management in hotels through the interest of distributing simple internal leaflets at the hotel departments, specifically the F\&B department to inform employees of the importance of quality management to improving employee's performance, hotel management should continuously encourage employees who work hard to apply quality management in a good and effective manner through the elements of motivation and promotion to obtain their satisfaction of employees.

\section{Recommendations}

Maximizing the role of the quality management in hotels through the interest of distributing simple internal leaflets in the hotel departments, especially the F\&B department to inform employees of the importance of quality management to improving employee's performance. Organizing continuous training courses for the employees and being implemented periodically at the food and beverage department especially in the field of quality and to know the latest methods and modern techniques used in hotels. It must be one of the most important interests of hotel management to obtain a certificate in the field of quality to keep pace with the development and increase the intensity of competition between hotels by maximizing its role hotel. Hotel management should continuously encourage staff working hard to implement the overall quality well and effectively through the elements of motivation and promotion to obtain their satisfaction and thus improve their work performance. The training department of the hotel must provide training courses to develop the performance of the staff through the following skills:

"How to deal with guests, good dealing with subordinates to achieve the best performance, always reach customer satisfaction because it is a guarantee to keep you working, Reduce the cost of the department during the recession without affecting the performance of employees, How to achieve a quality management system in the department, Focus on the elements of Quality dimensions, Establish a stable and advanced quality control system for hotels and impose sanctions on those who do not apply this system".

\section{Reference:}

Alin S.r., (2010)." Customer Satisfaction towards Service Quality of Front Office Staff at the Hotels ". Master Project Presented in Partial Fulfillment of the Requirements for the Master of Arts Degree in Business English for International Communication at Srina kharinwirot University. 
Barbara Bowes., (2009). "Improving Performance Management Systems", CMA Management, pp.12-13.

Bezerra, G.C., \& Gomes, C. F. (2015). The effects of service quality dimensions and passenger characteristics on passenger's overall satisfaction with an airport. Journal of Air Transport Management, 44, 77-81.

Biljana, A., (2011)." Measuring Customer Satisfaction with Service Quality Using American Customer Satisfaction Model (ACSI Model)", international Journal of Academic Research in Business and Social Sciences, October 2011, Vol. 1, No.3.pp.232-258.

Chapman, A.L. \& Linehan, M.M. (2005). Dialectical behavior therapy. In M. Zanarini (Ed.), Borderline Personality Disorder. New York: Marcel Dekker.

Constantinescu, M. (2011). "The relationship between quality of life and marketing ethics". Romanian Journal of Marketing, 3, 37-44.

Crick, P. A., \& Spencer, A. (2011). Hospitality quality: New directions and new challenges. International Journal of Contemporary Hospitality Management, 23(4), 463 - 478.

Crosby, Philip. B., (1979). "Quality is Free", the Art of Making Quality Certain, New York: McGraw-Hill, New American library.

Dale, Barrie. (2007). "Managing Quality", Five Editions, pp4-14.

Deming, W. E., (1982)." Quality, Productivity and Competitive Position", MITCenter for Advanced Engineering Studies, Cambridge.

Derven, M., (2010). "The paradox of performance appraisal". Personnel Journal 69 (2), 12-17.

Djabatey, Edward. (2012)." Recruitment and Selection Practices of Organizations "A Case Study of HFC Bank (GH) LTD", Executive Master Unpublished, Institute of Distance Learning, Kwame Nkrumah University of Science and Technology.pp14-22.

Evans J.R. and Lindsay W.M., (2008). "The Management and Control of Quality", 6 edition, Cincinnati, Ohio: south - western college publishing.

Feigenbaum, A. V. (1983). "Total Quality Control, 3rd (40th anniversary) ed". Rev., McGraw-Hill, Inc., New York.

Gryna, F.M., (2001)." Quality Planning and Analysis": From Product Development Through Use, Fourth Edition, Boston,MA, McGraw-Hill.p72.

Grzinic, J., (2007)." Concepts of Service Quality Measurement in the Hotel Industry", Pula: University Of Jurja Dobrile.p21.

Huseyin,B and Rukiye. K., (2015) " Service Quality in the Hospitality Industry: A Case of Merit Crystal Cove Hotel for Employees", American International Journal of Social Science Vol. 4, No. 1; pp: 126-133.

Ivana. B, Dragan. T and dorde. P., (2011). "Consumer Satisfaction and Quality Management in The Hospitality Industry In South-East Europe" African Journal of Business Management Vol. 5(4), pp 1388-1396.

Juran, J. M., (1988). "Editor, on Planning for Quality. Collier Macmillan, London.

Karapetrovic, S., Willborn, W., (2009). "Integration of Quality and Environmental Management Systems", TQM Magazine, vol. 10, no. 3, pp. 204-213.

Kipsegerwo .E. K., Kimutai .G. K. and Kimani Chege., (2016)." Effects of Performance Management Process on Employee Productivity": A Survey of Commercial Banks in Turkana County" IOSR Journal of Business and Management (IOSR-JBM). Volume 18, Issue 11. , pp.325-342.

Kosar, LJ. And Raseta, S., (2005). "Challenges to Quality - Quality Management in Hospitality Industry", College of Hotel Management, Belgrade. 
Ladhari, R. (2009). Service quality, emotional satisfaction, and behavioural intentions A study in the hotel industry. Journal of Managing Service Quality .Emerald Group Publishing Limited, 19(3), 309-331.

Melisidou, S. and Theocharis, N., (2010). "Service Quality, Customer Satisfaction and Customer Retention in the Hospitality Industry". Keys to achieve tourism growth. [online] Available from: http://74.125.155.132/scholar? Accessed 15 September 2010.

Mensah, I., (2009). "Customers' Perception of Food Service Quality: The Case of Cape Coast". Journal of Business and Enterprise Development, 1(1), 138-154.

Michael .A., (2006)." Human Resource Management Practice "(Kogan Page Ltd. Landon and Philadelphia), 10 Edition, pp131:135.

Naseem Afshan, Sadia Ejaz and Khusro P.G., (2011)." Improvement of Hotel Service Quality: An Empirical Research in Pakistan" International Journal of Multidisciplinary Sciences and Engineering, VOL. 2, NO. 5, August, pp.52-56.

Natuhwera .c., (2011). "Customer Care and Customer Satisfaction in Hotels. A Case Study Of Sheraton Hotel" Research Submitted To Maker ere University.

Nischithaa, P. \& Narasimha Rao., (2014), "The Importance of Training and Development Programs in Hotel Industry", International Journal of Business and Administration Research Review, 1(5), s. 50-56.

Pareek U. And T.V. Rao., (2006)." Designing and Managing Human Resource System", (Oxford and IBH Publishing Co. Pvt), Perspective" Journal of Service Research, 7 (1), pp. 20-41.

Prima .A. (2010)." The Functions and Responsibilities of Foods and Beverages Product Division in Sahib Jaya Hotel Solo" English Diploma Program, Faculty of Letters and Fine Arts Sebelas Maret University.

Quilliam, et al. (2014) "Characteristics of food averages that reach children and the nutrient quality of the food they advertise." Internet Research24 (10): 19.

Ramanathan, R., (2011)."Guests' Perceptions on Factors Influencing Customer Loyalty: An Analysis for UK Hotels", International Journal of Contemporary Hospitality Management, 23(1), 7-25.

Sheetal B.Sachdev and Harsh V.Verma, (2004). "Relative Importance Of Service Quality Dimensions: A Multispectral Study", Journal of Services Research, volume 4, N1.

Shi Jing-hua and Su Qiang., (2007)." Evaluation of Hotel Service Quality Based on Customer Satisfaction". IEEE. Services Marketing in Search of a New Paradigm and fresh.

Sila, I. (2007). "Examining the Effects of Contextual Factors on TQM and Performance through the Lens of Organizational Theories: An Empirical Study". Journal of Operations Management, 25, 83-109.

Spector, F. and Maurer, D. (2011). The colors of the alphabet: naturally-biased associations between shape and colors. Expert. Psychol.: Human Percept. Perform.17, 484-495.

Swart, J., Mann, C.,Brown, S. \& Price, A., (2005)." Human Resource Development: Strategy and Tactics". Oxford. Elsevier Butterworth-Heinemann Publications.

Viswanadhan, K. G., (2006). "Quality Assessment of Indian Engineering Programs: An Outcome-based Perspective". South Asian Journal of Management, 13(3), 76.

Vivienne McCabe and Nerilee Hing., (2010), "Management for Quality Tourism and Hospitality Services" Study Guide, Southern Cross University, 2 edition, pp.4871. 
Walker, J.R. (2016). "Introduction to Hospitality". New Jersey: Prentice Hall, Pearson Education, Inc, 7edition, pp57:62.

Widrick, S. M., Mergen, E., \& Grant, D. (2010). "Measuring the Dimensions of Quality in Higher Education". Total Quality Management, 13(1), 123-131.

William, B. (2008). "Service loyalty. The Effects of Service Quality and the Mediating Role of Customer Satisfaction". European Journal of Marketing, 34(11/12), 1338-1352.

Wu, C.H., Liao, H., Hung, K., \& Ho, Y., (2012). "Service Guarantees in the Hotel Industry: Their Effects on Consumer Risk and Service Quality Perceptions". International Journal of Hospitality Management, 31(3), 757-763.

Yarimoglu .E.K, (2014)," A Review on Dimensions of Service Quality Models", All Rights Reserved, Published by American Research Institute for Policy Development "Journal of Marketing Management, Vol. 2, No. 2, pp. 79-93.

Zeithaml, V.A. and Bitner, M., (2009)," Services Marketing: Integrating Customer Focus Across the firm" 2nd edition. New York: McGraw-Hill.

Zhang, J., (2016), "An Investigation into the Guests' Perceived Service Quality", Nelson Mandela Metropolitan University, South East European Journal of Economics and Business. p 56. 